\title{
Alkaloid Constituents of Ficus hispida and Their Antiinflammatory Activity
}

\author{
Xin-Yu Jia ${ }^{1} \cdot$ Yong-Mei Wu ${ }^{2} \cdot$ Jing-Ya $\mathrm{Li}^{2} \cdot$ Chun Lei $^{1} \cdot \mathrm{Ai}-J u n \mathrm{Hou}^{1}$
}

Received: 14 January 2020 / Accepted: 6 February 2020 / Published online: 18 February 2020

(c) The Author(s) 2020

\begin{abstract}
Four new alkaloids, ficuhismines A-D (1-4), together with three known ones, were isolated from Ficus hispida. Their structures were elucidated by spectroscopic analysis and chemical method. The new compounds represent the first amine alkaloids with a rhamnosyl moiety (1-2) or with a $N$-oxide motif (2-4) from the genus Ficus. Compound 2 showed potent inhibitory effect in nuclear factor- $\kappa \mathrm{B}(\mathrm{NF}-\kappa \mathrm{B})$ pathway luciferase assay with $\mathrm{IC}_{50}$ value of $0.52 \pm 0.11 \mu \mathrm{M}$.
\end{abstract}

Keywords Ficus hispida $\cdot$ Moraceae $\cdot$ Alkaloids $\cdot$ Antiinflammation $\cdot$ Nuclear factor- $\kappa B$

\section{Introduction}

The genus Ficus (Moraceae) comprises approximately 1000 species all over the world. They mainly distribute in tropical and subtropical areas and show diversity particularly in Southeast Asia [1]. In addition to the well-known fig ("Wu Hua Guo") and banyan trees, many Ficus plants possess important medicinal values. The plant Ficus hispida L.f. is a herbal medicine that has been used in China and India as a remedy for bronchitis, dysentery, rheumatism, and skin disorders $[2,3]$. The extracts from its different parts have been reported to show antiinflammatory, antidiabetic, antitumor, and hepatoprotective activities [4-7]. Primarily known for the rich flavonoids and triterpenoids [8], alkaloids

Dedicated to Professor Han-Dong Sun on the occasion of his 80th birthday.

Electronic supplementary material The online version of this article (https://doi.org/10.1007/s13659-020-00233-5) contains supplementary material, which is available to authorized users.

Chun Lei

chunlei@fudan.edu.cn

$\triangle$ Ai-Jun Hou

ajhou@shmu.edu.cn

1 School of Pharmacy, State Key Laboratory of Medical Neurobiology, Fudan University, Shanghai 201203, China

2 National Center for Drug Screening, Shanghai Institute of Materia Medica, Chinese Academy of Sciences, Shanghai 201203, China with antitumor and vasorelaxant activities have also been discovered from $F$. hispida $[9,10]$. Some alkaloids and $\alpha$-glucosidase inhibitory flavonoids from this plant have been reported previously by our group [11].

Nuclear factor- $\kappa \mathrm{B}(\mathrm{NF}-\kappa \mathrm{B})$ is a key regulator of inflammation. Activation of NF- $\kappa$ B initiates inflammation-associated metabolic disease, such as obesity, type 2 diabetes, and atherosclerosis [12]. In order to discover antiinflammatory natural products against metabolic diseases, alkaloid constituents of $F$. hispida were reinvestigated, and their inhibitory effects in NF- $\kappa$ B pathway luciferase assay were evaluated. Seven alkaloids including four new ones (ficuhismines A-D, 1-4) were isolated from the twigs and leaves of $F$. hispida (Fig. 1). The new compounds represent the first amine alkaloids with a rhamnosyl moiety (1-2) or with a $N$-oxide motif (2-4) from the genus Ficus. Compound 2 showed potent NF- $\kappa \mathrm{B}$ inhibitory activity. In this paper, the structural identification and bioactivity evaluation of the alkaloids are discussed.

\section{Results and Discussion}

Compound 1 was assigned the molecular formula $\mathrm{C}_{20} \mathrm{H}_{31} \mathrm{NO}_{6}$ by the (+)-HRESIMS ion at $m / z, 382.2232[\mathrm{M}+\mathrm{H}]^{+}$(calcd for $\left.\mathrm{C}_{20} \mathrm{H}_{32} \mathrm{NO}_{6}, 382.2224\right)$. The IR spectrum of $\mathbf{1}$ showed absorption bands for $\mathrm{OH}\left(3385 \mathrm{~cm}^{-1}\right)$, carbonyl $\left(1675 \mathrm{~cm}^{-1}\right)$, and aromatic $\left(1599 \mathrm{~cm}^{-1}\right)$ functionalities. The 1D NMR (Table 1) and HSQC spectra displayed signals of a carbonyl group $\left(\delta_{\mathrm{C}} 201.0, \mathrm{C}-7\right)$, a para-substituted benzene ring $\left(\delta_{\mathrm{H}}\right.$ 
<smiles>[R]Oc1ccc(C(=O)CCCCCN(C)C)cc1</smiles>

$1 \mathrm{R}=\alpha-\mathrm{L}-\mathrm{Rha}$

$5 \mathrm{R}=\mathrm{H}$<smiles>COc1cc(CCN(C)C)ccc1O</smiles><smiles>[R]Oc1ccc(C(=O)CCCCC[N+](C)(C)[O-])cc1</smiles><smiles>COc1ccc(CC[N+](C)(C)[O-])cc1O</smiles>

4<smiles>C[N+]1(C)CCCC1CC(=O)c1ccc(O)cc1</smiles><smiles>C[C@@H]1O[C@H](C)[C@@H](O)[C@H](O)[C@H]1O</smiles>

Fig. 1 Structures of compounds 1-7

Table $1{ }^{1} \mathrm{H}(400 \mathrm{MHz})$ and ${ }^{13} \mathrm{C}(150 \mathrm{MHz})$ NMR data for compounds 1-4 (in methanol- $d_{4}$ )

\begin{tabular}{|c|c|c|c|c|c|c|c|c|}
\hline \multirow[t]{2}{*}{ Pos. } & \multicolumn{2}{|l|}{1} & \multicolumn{2}{|l|}{2} & \multicolumn{2}{|l|}{3} & \multicolumn{2}{|l|}{4} \\
\hline & $\delta_{\mathrm{H}}(J$ in $\mathrm{Hz})$ & $\delta_{\mathrm{C}}$ & $\delta_{\mathrm{H}}(J$ in $\mathrm{Hz})$ & $\delta_{\mathrm{C}}$ & $\delta_{\mathrm{H}}(J$ in $\mathrm{Hz})$ & $\delta_{\mathrm{C}}$ & $\delta_{\mathrm{H}}(J$ in $\mathrm{Hz})$ & $\delta_{\mathrm{C}}$ \\
\hline $2 \mathrm{H}$ & $3.10(\mathrm{~m})$ & 58.9 & $3.63(\mathrm{~m})$ & 70.5 & $3.61(\mathrm{~m})$ & 70.5 & $3.43(\mathrm{~m})$ & 73.0 \\
\hline 3 & $1.72(\mathrm{~m})$ & 25.5 & $1.92(\mathrm{~m})$ & 23.9 & $1.90(\mathrm{~m})$ & 23.9 & $3.04(\mathrm{~m})$ & 30.4 \\
\hline 4 & $1.43(\mathrm{~m})$ & 27.0 & $1.47(\mathrm{~m})$ & 26.7 & $1.45(\mathrm{~m})$ & 26.8 & & 129.1 \\
\hline 5 & $1.74(\mathrm{~m})$ & 24.8 & $1.78(\mathrm{~m})$ & 24.8 & $1.76(\mathrm{~m})$ & 25.0 & 6.67 (br d, 8.0) & 122.5 \\
\hline 6 & $3.01(\mathrm{t}, 6.8)$ & 38.6 & $3.04(\mathrm{t}, 7.2)$ & 38.6 & $2.99(\mathrm{t}, 7.2)$ & 38.4 & $6.70(\mathrm{~d}, 8.0)$ & 116.7 \\
\hline 7 & & 201.0 & & 200.9 & & 201.0 & & 149.5 \\
\hline 8 & & 132.3 & & 132.3 & & 130.0 & & 147.3 \\
\hline 9 & $7.96(\mathrm{~d}, 8.8)$ & 131.4 & $7.97(\mathrm{~d}, 8.8)$ & 131.4 & $7.87(\mathrm{~d}, 8.8)$ & 131.8 & 6.85 (br s) & 113.6 \\
\hline 10 & $7.13(\mathrm{~d}, 8.8)$ & 117.1 & $7.15(\mathrm{~d}, 8.8)$ & 117.1 & $6.82(\mathrm{~d}, 8.8)$ & 116.3 & & \\
\hline 11 & & 161.8 & & 161.8 & & 163.9 & & \\
\hline 12 & $7.13(\mathrm{~d}, 8.8)$ & 117.1 & $7.15(\mathrm{~d}, 8.8)$ & 117.1 & $6.82(\mathrm{~d}, 8.8)$ & 116.3 & & \\
\hline 13 & $7.96(\mathrm{~d}, 8.8)$ & 131.4 & $7.97(\mathrm{~d}, 8.8)$ & 131.4 & $7.87(\mathrm{~d}, 8.8)$ & 131.8 & & \\
\hline $1^{\prime}$ & 5.52 (br s) & 99.6 & $5.53(\mathrm{br} \mathrm{s})$ & 99.6 & & & & \\
\hline $2^{\prime}$ & 3.98 (br s) & 71.8 & $4.00(\mathrm{br} \mathrm{s})$ & 71.8 & & & & \\
\hline $3^{\prime}$ & $3.81(\mathrm{dd}, 9.6,3.2)$ & 72.1 & $3.82(\mathrm{dd}, 9.3,3.3)$ & 72.2 & & & & \\
\hline $4^{\prime}$ & $3.44(t, 9.6)$ & 73.7 & 3.46 (overlap) & 73.7 & & & & \\
\hline $5^{\prime}$ & $3.54(\mathrm{~m})$ & 71.0 & $3.55(\mathrm{~m})$ & 71.0 & & & & \\
\hline $6^{\prime}$ & $1.18(\mathrm{~d}, 6.0)$ & 18.0 & $1.20(\mathrm{~d}, 6.0)$ & 18.0 & & & & \\
\hline $\mathrm{Me}_{2} \mathrm{~N}$ & $2.85(\mathrm{~s})$ & 43.4 & $3.46(\mathrm{~s})$ & 56.4 & $3.45(\mathrm{~s})$ & 56.4 & $3.17(\mathrm{~s})$ & 58.6 \\
\hline $\mathrm{MeO}$ & & & & & & & $3.82(\mathrm{~s})$ & 56.4 \\
\hline
\end{tabular}

7.96, H-9/H-13; 7.13, H-10/H-12; $\delta_{\mathrm{C}} 132.3$, C-8; 131.4, C-9/ C-13; 117.1, C-10/C-12; 161.8, C-11), a rhamnopyranosyl moiety $\left(\delta_{\mathrm{H}} 5.52, \mathrm{H}-1^{\prime} ; 3.98\right.$, H-2'; 3.81, H-3'; 3.44, H-4'; 3.54, $\mathrm{H}-5^{\prime} ; 1.18, \mathrm{H}_{3}-6^{\prime} ; \delta_{\mathrm{C}} 99.6, \mathrm{C}-1^{\prime} ; 71.8, \mathrm{C}-2^{\prime} ; 72.1, \mathrm{C}-3^{\prime} ; 73.7$, C-4'; 71.0, C-5'; 18.0, C-6'), a dimethylamino moiety $\left(\delta_{\mathrm{H}}\right.$ $\left.2.85 ; \delta_{\mathrm{C}} 43.4\right)$, and five methylenes. The anomeric configuration of the L-rhamnopyranosyl moiety was determined as $\alpha$ by the chemical shifts of $\mathrm{C}^{-} 3^{\prime}$ and $\mathrm{C}-5^{\prime}$ [13]. The aforementioned information indicated $\mathbf{1}$ was an amine alkaloid rhamnoside. In the HMBC spectrum (Fig. 2), the correlations of $\mathrm{H}_{2}-2 / \mathrm{Me}_{2} \mathrm{~N}, \mathrm{C}-3 ; \mathrm{H}_{2}-4 / \mathrm{C}-2$, C-3, C-5, C-6; $\mathrm{H}_{2}-6 / \mathrm{C}-5$, C-7; H-9/C-7, C-10, C-11, C-13; and H-10/C-8, C-11, C-12 constructed the aglycone motif as a 6-(dimethylamino)-1(4-hydroxyphenyl)-1-hexanone. The H-1'/C-11 HMBC correlation indicated that the sugar was connected to $\mathrm{C}-11$. Acid hydrolysis of $\mathbf{1}$ afforded the aglycone and sugar units. The sugar was verified as L-rhamnose by TLC analysis and comparing its specific rotation $\left([\alpha]_{D}^{25}=+6.0\right)$ with that of the 

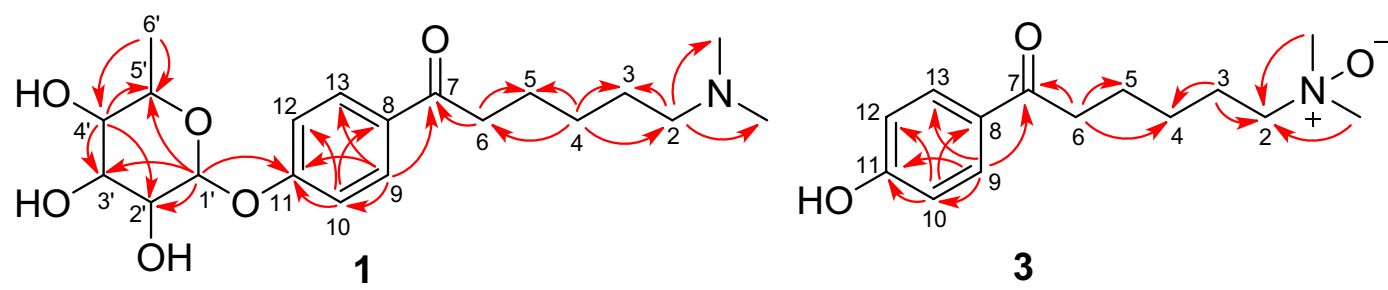

3
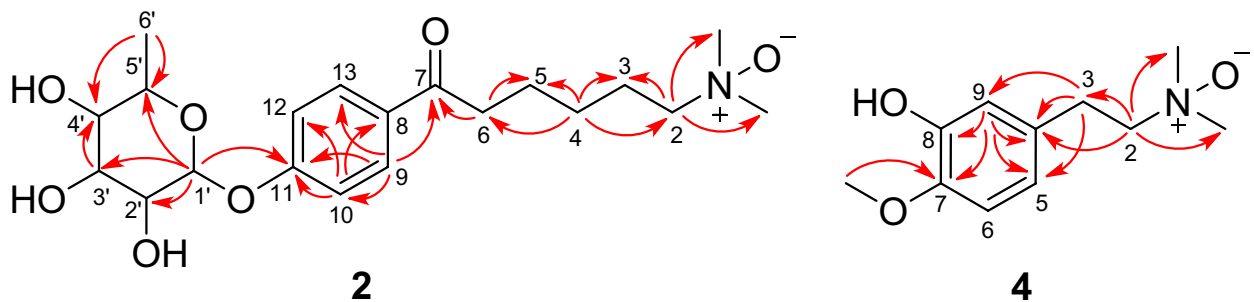

Fig. 2 Key HMBC $(\mathrm{H} \rightarrow \mathrm{C})$ correlations of compounds 1-4

authentic L-rhamnose $\left([\alpha]_{\mathrm{D}}^{25}=+8.0\right)$. Thus, the structure of 1 was elucidated as depicted, and the compound was given the name ficuhismine A.

Compound 2 was assigned the molecular formula $\mathrm{C}_{20} \mathrm{H}_{31} \mathrm{NO}_{7}$ by the (+)-HRESIMS $\left(\mathrm{m} / z\right.$ 398.2165 $[\mathrm{M}+\mathrm{H}]^{+}$; calcd for $\mathrm{C}_{20} \mathrm{H}_{32} \mathrm{NO}_{7}, 398.2173$ ), indicating six indices of hydrogen deficiency. Analysis of its NMR data (Table 1) implied that 2 possessed the same $\alpha$-rhamnopyranosyl and para-substituted benzene moieties as $\mathbf{1}$. The only difference was the 6-(dimethylamino)-1-hexanone side chain. In the ${ }^{13} \mathrm{C}$ NMR spectrum of $\mathbf{2}$, the obviously deshielded carbon signals of the dimethylamino moiety $\left(\Delta \delta_{\mathrm{C}}+13.0\right)$ and the methylene at C-2 $\left(\Delta \delta_{\mathrm{C}}+11.6\right)$ were observed. In consideration the indices of hydrogen deficiency and an additional oxygen atom in the molecular formula of $\mathbf{2}$, the presence of a $\mathrm{N}$-oxide motif was inferred. The HMBC data shown in Fig. 2 confirmed the structure of $\mathbf{2}$. The sugar was identified as L-rhamnose by the same protocol as that of $\mathbf{1}$. Compound $\mathbf{2}$ was thus elucidated as an $N$-oxide of $\mathbf{2}$ and named ficuhismine B.

Compound 3 was assigned the molecular formula $\mathrm{C}_{14} \mathrm{H}_{21} \mathrm{NO}_{3}$ by the (+)-HRESIMS ion at $\mathrm{m} / z, 252.1595$ $[\mathrm{M}+\mathrm{H}]^{+}$(calcd for $\left.\mathrm{C}_{14} \mathrm{H}_{22} \mathrm{NO}_{3}, 252.1594\right)$. Its 1D (Table 1) and 2D NMR data (Fig. 2) indicated that 3 was an aglycone of $\mathbf{2}$. The structure of $\mathbf{3}$ was thus elucidated, and the compound was named ficuhismine $\mathrm{C}$.

Compound 4 was assigned the molecular formula $\mathrm{C}_{11} \mathrm{H}_{17} \mathrm{NO}_{3}$ by the (+)-HRESIMS ion at $\mathrm{m} / \mathrm{z} 212.1281$ $[\mathrm{M}+\mathrm{H}]^{+}$(calcd for $\left.\mathrm{C}_{11} \mathrm{H}_{18} \mathrm{NO}_{3}, 212.1281\right)$. The ${ }^{1} \mathrm{H}$ and ${ }^{13} \mathrm{C}$ NMR spectra of 4 (Table 1) revealed signals for a dimethylamino moiety, two methylenes, a methoxy group, and a 1,2, 5-trisubstituted benzene motif. Similar to $\mathbf{2}$ and $\mathbf{3}$, the downfield-shifted ${ }^{13} \mathrm{C}$ resonances of the dimethylamino moiety and the methylene at $\mathrm{C}-2$ proved that $\mathbf{4}$ was also an amino alkaloid $\mathrm{N}$-oxide. The HMBC correlations of $\mathrm{H}_{2}-2 / \mathrm{Me}_{2} \mathrm{~N}$,
C-3, C-4; $\mathrm{H}_{2}-3 / \mathrm{C}-4, \mathrm{C}-5$, C-9; H-9/C-4, C-5, C-7, C-8; and $\mathrm{MeO} / \mathrm{C}-7$ (Fig. 2) confirmed the structure of 4 as depicted. The structure of $\mathbf{4}$ was thus elucidated, and the compound was named ficuhismine $\mathrm{D}$.

The known compounds were identified as ficushispimine C (5) [11] magnosprengerine (6) [14], and ficushispimine A (7) [11] (Fig. 1) by comparison of their spectroscopic data with those reported.

All the isolated alkaloids were tested in vitro for their antiinflammatory effects. Ficuhismine B (2) exhibited significant inhibitory activity in NF- $\kappa$ B pathway luciferase assay with $\mathrm{IC}_{50}$ value of $0.52 \pm 0.11 \mu \mathrm{M}$. Bortezomib (PS-341) was used as the positive control $\left(\mathrm{IC}_{50}=0.12 \pm 0.04 \mu \mathrm{M}\right)$ in this test. All the other compounds were inactive. It seemed that both L-rhamnosyl and $\mathrm{N}$-oxide moieties are necessary for the NF- $\kappa$ B inhibition.

Alkaloids are one of the main bioactive ingredients of $F$. hispida. Amphetamine [9, 11], piperidine [9], pyrrolidine $[10,11]$, and isoquinoline [15] alkaloids have been reported from this plant previously. In this research, amine alkaloids with a rhamnosyl group (1-2) or with a $N$-oxide moiety (2-4) were discovered for the first time from the genus Ficus. Compound 2 with both rhamnosyl and $N$-oxide moieties showed potent NF- $\kappa$ B inhibitory activity, which may provide useful information for mining or designing drug leads against inflammation-related metabolic diseases.

\section{Experimental Section}

\subsection{General Experimental Procedures}

Optical rotations were recorded on a Rudolph Autopol IV-T polarimeter. UV spectra were recorded on a Hitachi U-2900 UV-Vis spectrophotometer. IR spectra were recorded on 
a ThermoFisher Nicolet iS5 FT-IR spectrometer. NMR spectra were acquired on Varian Mercury Plus 400 instrument and Bruker Avance III HD 600 spectrometer using $\mathrm{CD}_{3} \mathrm{OD}\left(\delta_{\mathrm{H}} 3.31\right.$ and $\left.\delta_{\mathrm{C}} 49.0\right)$. HRESIMS were obtained on an AB SCIEX 5600+Q-TOF mass spectrometer. MCI gel CHP-20P (75-150 $\mu \mathrm{m}$, Mitsubishi Chemical Corporation, Tokyo, Japan), ODS gel (50 $\mu \mathrm{m}$, YMC Co., Ltd., Japan), and Sephadex LH-20 gel (GE Healthcare Bio-Sciences, USA) were used for column chromatography. Precoated silica gel GF254 plates (Qingdao Haiyang Chemical Co., Ltd., China) were used for TLC analysis. Semi-preparative HPLC was performed on a Shimadzu Essentia LC-16 with a UV detector (210 and $254 \mathrm{~nm}$ ) and a Kromasil $\mathrm{C}_{18}$ column $(150 \times 10 \mathrm{~mm}, 5 \mu \mathrm{m}$, AkzoNobel, Co., Sweden).

\subsection{Plant Material}

The twigs and leaves of Ficus hispida were collected in Puer City, Yunnan Province, People's Republic of China, in September 2015. The plant material was identified by Dr. Yun Kang, School of Pharmacy, Fudan University. A voucher specimen (TCM 2015-09-02 Hou) has been deposited at the Herbarium of the Department of Pharmacognosy, School of Pharmacy, Fudan University.

\subsection{Extraction and Isolation}

The plant material $(10.0 \mathrm{~kg})$ was ground and percolated with $95 \% \mathrm{EtOH}(30 \mathrm{~L})$ at room temperature. The filtrate was evaporated under reduced pressure to produce a crude extract $(1.5 \mathrm{~kg})$. It was dissolved in tartaric acid solution ( $\mathrm{pH} 2.0)$, basified using saturated sodium carbonate solution to $\mathrm{pH} \mathrm{13}$, and then partitioned with $\mathrm{CHCl}_{3}$ to give a total alkaloid extract $(1.2 \mathrm{~g})$. This extract was subjected to $\mathrm{MCI}$ column chromatography $(\mathrm{CC})\left(\mathrm{MeOH} / \mathrm{H}_{2} \mathrm{O}\right.$, from 1:9 to 10:0) to provide fractions A-E. Fractions A-D were separated over CC (ODS gel, $\mathrm{MeOH} / \mathrm{H}_{2} \mathrm{O}, 10: 90,20: 80$, 30:70, 100:0) to give fractions A1-A4, B1-B4, C1-C4, and D1-D4, respectively. Fr. A1 was loaded on a Sephadex LH-20 column $\left(\mathrm{CH}_{2} \mathrm{Cl}_{2} / \mathrm{MeOH}, 1: 1\right)$ and then purified by semi-preparative $\mathrm{HPLC}\left(\mathrm{MeOH} / \mathrm{H}_{2} \mathrm{O}, 9: 91\right.$, flow rate $2 \mathrm{~mL} /$ $\mathrm{min})$ to afford $\mathbf{3}\left(2.3 \mathrm{mg}, t_{\mathrm{R}} 16.5 \mathrm{~min}\right)$. Fractions A2 and B1 were purified by semi-preparative HPLC to give 5 (MeCN/ $\mathrm{H}_{2} \mathrm{O}, 16: 84$, flow rate $2 \mathrm{~mL} / \mathrm{min}, 2.3 \mathrm{mg}, t_{\mathrm{R}} 23 \mathrm{~min}$ ) and 7 ( $\mathrm{MeCN} / \mathrm{H}_{2} \mathrm{O}, 6: 94$, flow rate $2 \mathrm{~mL} / \mathrm{min}, 2.5 \mathrm{mg}, t_{\mathrm{R}} 15 \mathrm{~min}$ ), respectively. Compounds $4\left(\mathrm{MeOH} / \mathrm{H}_{2} \mathrm{O}, 3: 97\right.$, flow rate $\left.4 \mathrm{~mL} / \mathrm{min}, 5.0 \mathrm{mg}, t_{\mathrm{R}} 31 \mathrm{~min}\right)$ and $6\left(\mathrm{MeCN} / \mathrm{H}_{2} \mathrm{O}, 10: 90\right.$, flow rate $2 \mathrm{~mL} / \mathrm{min}, 1.5 \mathrm{mg}, t_{\mathrm{R}} 26 \mathrm{~min}$ ) were isolated by semi-preparative HPLC from fractions $\mathrm{C} 1$ and $\mathrm{C} 2$, respectively. Compounds $2\left(\mathrm{MeOH} / \mathrm{H}_{2} \mathrm{O}, 3: 97\right.$, flow rate $4 \mathrm{~mL} /$ min, $\left.2.0 \mathrm{mg}, t_{\mathrm{R}} 31 \mathrm{~min}\right)$ and $\mathbf{1}\left(\mathrm{MeCN} / \mathrm{H}_{2} \mathrm{O}, 11: 89\right.$, flow rate $4 \mathrm{~mL} / \mathrm{min}, 2.0 \mathrm{mg}, t_{\mathrm{R}} 16.0 \mathrm{~min}$ ) were purified by semipreparative HPLC from fractions D1 and D3, respectively.

\subsection{Spectroscopic Data of Compounds}

\subsubsection{Ficuhismine A (1)}

White solid; $[\alpha]_{\mathrm{D}}^{25}=-61.0($ c $0.1, \mathrm{MeOH})$; UV $(\mathrm{MeOH})$ $\lambda_{\text {max }}(\log \varepsilon) 206$ (4.28), 262 (4.32) nm; IR (KBr) $\nu_{\max } 3385$, $2915,1675,1599,1383,1181,1141,1075,632 \mathrm{~cm}^{-1} ;{ }^{1} \mathrm{H}$ NMR and ${ }^{13} \mathrm{C}$ NMR data: Table 1; HRESIMS $m / z 382.2232$ $[\mathrm{M}+\mathrm{H}]^{+}$(calcd for $\left.\mathrm{C}_{20} \mathrm{H}_{32} \mathrm{NO}_{6}, 382.2224\right)$.

\subsubsection{Ficuhismine B (2)}

White solid; $[\alpha]_{\mathrm{D}}^{25}=-70.0(c 0.1, \mathrm{MeOH})$; UV $(\mathrm{MeOH})$ $\lambda_{\max }(\log \varepsilon) 206$ (4.32), $264(4.41) \mathrm{nm}$; IR (KBr) $\nu_{\max } 3372$, 2935, 1675, 1600, 1421, 1196, 1179, 1140, 1073, 1014, 971, $835 \mathrm{~cm}^{-1}$; ${ }^{1} \mathrm{H}$ NMR and ${ }^{13} \mathrm{C}$ NMR data: Table 1; HRESIMS $m / z$ 398.2165 $[\mathrm{M}+\mathrm{H}]^{+}$(calcd for $\mathrm{C}_{20} \mathrm{H}_{32} \mathrm{NO}_{7}, 398.2173$ ).

\subsubsection{Ficuhismine C (3)}

White solid; UV (MeOH) $\lambda_{\text {max }}(\log \varepsilon) 204$ (3.87), 216 (3.90), $274(4.03) \mathrm{nm}$; IR (KBr) $\nu_{\max } 3412,2914,1674,1604$, 1193, 1178, 1142, 1073, $637 \mathrm{~cm}^{-1} ;{ }^{1} \mathrm{H}$ NMR and ${ }^{13} \mathrm{C}$ NMR data: Table 1; HRESIMS $m / z, 252.1595[\mathrm{M}+\mathrm{H}]^{+}$(calcd for $\left.\mathrm{C}_{14} \mathrm{H}_{22} \mathrm{NO}_{3}, 252.1594\right)$.

\subsubsection{Ficuhismine $D(4)$}

White solid; UV (MeOH) $\lambda_{\max }(\log \varepsilon) 204$ (3.81), 216 (3.80), 274 (3.97) nm; IR (KBr) $\nu_{\max } 3409,2950,2937,2855,2581$, 1599, 1524, 1454, 1387, 1280, $1033 \mathrm{~cm}^{-1}$; ${ }^{1} \mathrm{H}$ NMR and ${ }^{13} \mathrm{C}$ NMR data: Table 1; HRESIMS $m / z, 212.1281[\mathrm{M}+\mathrm{H}]^{+}$ (calcd for $\mathrm{C}_{11} \mathrm{H}_{18} \mathrm{NO}_{3}, 212.1281$ ).

\subsection{Acid Hydrolysis of Compounds 1 and 2}

Compound $1(1 \mathrm{mg})$ was added to a solution of $\mathrm{H}_{2} \mathrm{O}(3 \mathrm{~mL})$, dioxane $(3 \mathrm{~mL})$, and $\mathrm{HCl}(0.5 \mathrm{~mL})$, and then kept at $60^{\circ} \mathrm{C}$ for $4 \mathrm{~h}$. The reaction mixture was quenched with $\mathrm{NaHCO}_{3}$ and extracted with EtOAc. The aqueous phase was concentrated under reduced pressure. The residue was dissolved in $\mathrm{H}_{2} \mathrm{O}$ for TLC analysis with the authentic L-rhamnose (EtOAc/ $\left.\mathrm{MeOH} / \mathrm{AcOH} / \mathrm{H}_{2} \mathrm{O}, 10: 3: 3: 2, \mathrm{v} / \mathrm{v}, \mathrm{R}_{\mathrm{f}}: 0.6\right)$ and for optical rotation measurement $\left\{\right.$ the aqueous phase: $[\alpha]_{\mathrm{D}}^{25}=+6.0(c$ $\left.0.1 \mathrm{H}_{2} \mathrm{O}\right)$; L-rhamnose: $\left.[\alpha]_{\mathrm{D}}^{25}=+8.0\left(c 0.1 \mathrm{H}_{2} \mathrm{O}\right)\right\}$. Compound 2 was operated in the same way as $\mathbf{1}$. 


\subsection{Luciferase Assay}

HEK293/NF- $\kappa$ B cells were prepared as reported [16]. The luciferase assay procedure was performed according to the reported methods [17]. The $\mathrm{IC}_{50}$ values were calculated using Graphpad prism 8.

Acknowledgements Financial supports from the National Natural Science Foundation of China (Grant Nos. 81222045 and 21672040) and the Drug Innovation Major Project of China (Grant No. 2018ZX09735001-002-006) are gratefully acknowledged.

\section{Compliance with Ethical Standards}

Conflict of interest The authors declare no conflict of interest.

Open Access This article is licensed under a Creative Commons Attribution 4.0 International License, which permits use, sharing, adaptation, distribution and reproduction in any medium or format, as long as you give appropriate credit to the original author(s) and the source, provide a link to the Creative Commons licence, and indicate if changes were made. The images or other third party material in this article are included in the article's Creative Commons licence, unless indicated otherwise in a credit line to the material. If material is not included in the article's Creative Commons licence and your intended use is not permitted by statutory regulation or exceeds the permitted use, you will need to obtain permission directly from the copyright holder. To view a copy of this licence, visit http://creativecommons.org/licenses/by/4.0/.

\section{References}

1. Z. Zhou, M.G. Gilbert, Flora China 5, 37-71 (2003)
2. M. Shahriar, S. Islam, S. Parvin, S. Hoque, J. Sci. Res. 5, 393-397 (2013)

3. L.X. Zhang, Z.B. Guan, Subtrop. Plant Sci. 33, 60-62 (2004)

4. M.S.I. Howlader, M.A. Siraj, S.K. Dey, A. Hira, A. Ahmed, M.H. Hossain, Evid-Based Compl. Alt. 7390359 (2017)

5. P. Deepa, K. Sowndhararajan, S. Kim, S.J. Park, J. Ethnopharmacol. 215, 210-232 (2018)

6. B. Pratumvinit, T. Srisapoomi, P. Worawattananon, N. Opartkiattikul, W. Jiratchariyakul, T. Kummalue, J. Med. Plants Res. 3, 255-261 (2009)

7. S.C. Mandal, B. Saraswathi, C.K. Kumar, S.M. Lakshmi, B.C. Maiti, Phytother. Res. 14, 457-459 (2000)

8. J.X. Cheng, B.D. Zhang, W.F. Zhu, C.F. Zhang, Y.M. Qin, M. Abe, T. Akihisa, W.Y. Liu, F. Feng, J. Zhang, J. Ethnopharmacol. 248, 112204 (2020)

9. V.A. Yap, B.J. Loong, K.N. Ting, S.H. Loh, K.T. Yong, Y.Y. Low, T.S. Kam, K.H. Lim, Phytochemistry 109, 96-102 (2015)

10. J. Zhang, W.F. Zhu, J. Xu, W. Kitdamrongtham, A. Manosroi, J. Manosroi, H. Tokuda, M. Abe, T. Akihisa, F. Feng, J. Ethnopharmacol. 214, 37-46 (2018)

11. Z.F. Shi, C. Lei, B.W. Yu, H.Y. Wang, A.J. Hou, Chem. Biodivers. 13, 445-450 (2016)

12. R.G. Baker, M.S. Hayden, S. Ghosh, Cell Metab. 13, 11-22 (2011)

13. K. Nishimura, T. Miyase, H. Noguchi, J. Nat. Prod. 62, 1128-1133 (1999)

14. Z.Q. Cao, H.G. Li, Y.J. Tian, F.F. Mu, J.P. Yang, M.L. Wang, N.N. Zhao, Chin. Tradit. Herbal Drugs 16, 386-388 (1985)

15. W. Xu, P. Wang, S.Z. Li, Q.S. Song, Nat. Prod. Res. Dev. 22, 1003-1005 (2010)

16. Y.M. Peng, J.B. Zheng, Y.B. Zhou, J. Li, Acta Pharmacol. Sin. 34, 939-950 (2013)

17. X. Jia, Y. Wu, C. Lei, Y. Yu, J. Li, J. Li, A. Hou, Chin. Chem. Lett. (2019). https://doi.org/10.1016/j.cclet.2019.10.014 